\title{
Circulating in the blood desquamated endotheliocytes at the diabetic nephropathy
}

\author{
A.I. Gozhenko, H.S. Kuznetsova, K.S. Kuznetsova, T.M. Byts, E.A. Gozhenko, \\ N.O. Shevchenko
}

State Enterprise "Ukrainian Research Institute of Transport Medicine, Ministry of Health of Ukraine”, Odessa; e-mail: prof.gozhenko@gmail.com, hanna.serg.kuznetsova@gmail.com

\begin{abstract}
The aim of the study was to determine the role of endothelial dysfunction (ED) in the pathogenesis of diabetic nephropathy (DN) in patients with diabetes mellitus (DM) 1 and 2 type with a severe course (state of decompensation). DN was manifested by a decrease in GFR and urinary syndrome. In patients with diabetes, depending on the glomerular filtration rate (GFR), ED was estimated by the number of circulating desquamation endothelial cells (CECs) with the simultaneous determination of $\mathrm{NO}_{2}^{-}$and $\mathrm{NO}_{3}{ }^{-}$metabolites. The indicators of the urinary syndrome don't correlate with the degree of GFR reduction. The concentration of CECs in blood plasma in patients with GFR $\geq 90 \mathrm{ml} \cdot \mathrm{min}^{-1} \cdot 1.73 \mathrm{~m}^{-2}$ was $3053 \pm 210.1 \mathrm{cell} / \mathrm{sl}$. The level of endotheliocythemia in patients with GFR from 42 to $88 \mathrm{ml} \cdot \mathrm{min}^{-1} \cdot 1.73 \mathrm{~m}^{-2}$ was $22 \%$ higher and amounted to $3700 \pm 260.6$ cells $/ \mathrm{ml}$. Therefore, in the patients with DN, the number of CECs in blood plasma increases. Key words: diabetes mellitus; endothelial dysfunction; diabetic nephropathy; circulating endothelial cells; glomerular filtration rate; vascular endothelium; nitric oxide.
\end{abstract}

\section{INTRODUCTION}

The pathology of the kidneys in patients with diabetes mellitus (DM) is one of the main problems of modern diabetology and nephrology. The rapid increase in the incidence of diabetes in the whole world and in Ukraine is the reason that constant qualitative monitoring of the pathological process in the kidneys and pathogenetically grounded nephroprotection are necessary [1-3]. Diabetic nephropathy (DN) for a long time was characterized by a specific lesion of the renal parenchyma leading to the formation of nodular or diffuse glomerulosclerosis [4-5]. To date, the understanding of the development of renal damage at DM has been significantly expanded, and the leading factors in the progression of renal pathology are presented in the form of metabolic (hyperglycemia, dyslipidemia), hemodynamic (increased intracolubic and arterial pressure), genetically determined and pre-acquired factors, and also due to endothelial dysfunction $[6,7]$.

Hyperglycemia is the main initiating meta- bolic factor in the development of diabetic nephropathy, which has a damaging effect on all kidney structures - podocytes, mesangial and endothelial cells, basal membrane of the glomerulus, tubular epithelium and vascular epithelium, and also interstitial fibroblasts [8, 9]. In conditions of hyperglycemia, glucose self-oxidizes to diacylglycerol, a powerful stimulator of protein kinase $\mathrm{C}$ activity, which is involved in the activation of inflammatory and profibrotic cytokines, growth factors, With the subsequent stimulation of secretion of vasoactive prostanoids, which promotes the development of nephrosclerosis [10, 11].

In recent years, special attention has been paid to the pathogenetic role of endothelial dysfunction (ED) in the development of major complications of diabetes [12]. However, the main works on cardiovascular pathology are devoted to ED in cardiovascular pathology in hypertension, coronary heart disease, chronic heart failure, strokes and atherosclerosis [13]. At the same time, studies on the role of ED in

(C) A.I. Gozhenko, H.S. Kuznetsova, K.S. Kuznetsova, T.M. Byts, E.A. Gozhenko, N.O. Shevchenko 
the development of DN are not enough. In this regard, it was of interest to examine the role of ED in the development and progression of DN.

\section{METHODS}

The study involved 53 patients with type 1 and type 2 diabetes. Among the patients with diabetes, $32(60.4 \%)$ were males and $21(39.6 \%)$ were females, with a mean age of $55.6 \pm 3.9$ (from 19 to 80 years). The length of diabetes was in the range of 2 to 45 years, and averaged $13.3 \pm 2.4$ years.

Determination of the intensity of endothelium desquamation (endotheliocythemia) was used with simultaneous determination of the level of nitric oxide (NO) production by the content of its stable metabolites - nitrite $\left(\mathrm{NO}_{2}^{-}\right)$ and nitrate anions $\left(\mathrm{NO}_{3}^{-}\right)$in blood plasma. CECs were determined by the method of J. Hladovek [14]. Platelet-rich plasma (PRP) was prepared by centrifugation ( $1000 \mathrm{~g}$ for $10 \mathrm{~min}$ ). After the addition of $0.2 \mathrm{ml}$ of Adenosine-Diphosphate to $1 \mathrm{ml}$ of PRP the mixture was shaken mechanically for $10 \mathrm{~min}$. Another centrifugation (1000 $\mathrm{g}$ for $10 \mathrm{~min}$ ) served to remove platelet aggregates. The supernatant was centrifuged at 3000 $\mathrm{g}$ for $15 \mathrm{~min}$ and the very scanty sediment was carefully suspended in $0.1 \mathrm{ml}$ of $0.9 \% \mathrm{NaC} 1$ by stirring with a glass rod. From the suspension two platforms of a Goryaev's chamber were filled and cells were counted by the method of phase contrast microscopy using a Micromed XS-3320 binocular microscope, Plan $10 \mathrm{Ph} / 0.25$ lens (10 fold) and eyepieces WF 16X. CECs are well characterized by their size and shape and cannot be mistaken for anything else [14-16]. The cells represent polygonal objects approximately 30-50 $\mu \mathrm{m}$ in diameter. They often show folded or roiled margins suggesting an extreme thinnes of less than $1 \mu \mathrm{m}$. Considering the ratio between the number of cells in platforms and the volume of the Goriaev's chamber, the volume of the resulting suspension and the volume of blood plasma, we calculate the number of CECs in $1 \mathrm{ml}$ of blood plasma. The $\mathrm{NO}_{2}{ }^{-}$concentration was determined by the Green method using a Griss reagent, the concentration of $\mathrm{NO}_{3}{ }^{-}$after their reduction to nitrite using zinc dust [15].

The functional state of the kidneys was estimated by the indicators of urinary syndrome, microalbuminuria, GFR, and creatinine serum levels. Due to the fact that the current guidelines of the National Kidney Foundation (KDOQI) for CKD screening recommend that GFR be evaluated either by creatinine clearance or by MDRD or CKD-EPI formulas, as the most optimal option from indirect diagnostic methods [17]. We evaluated the GFR using the formula EPI:

$\mathrm{GFR}=141 \cdot \min \left(\mathrm{S}_{\mathrm{Cr}} / \mathrm{k}, 1\right)^{\alpha} \cdot \max \left(\mathrm{S}_{\mathrm{Cr}} / \mathrm{k}, 1\right)^{-1.200}$. $0.993^{\text {age }} \cdot[1,018$ if female], where $\mathrm{S}_{\mathrm{Cr}}-$ standardized serum creatinine $(\mathrm{mg} / \mathrm{dL})$,

$\mathrm{k}-0.7$ (females) or 0.9 (males), $\alpha--0.329$

(females) or 0.411 (males).

Statistical analysis was performed using STATISTICA for Excel program. In describing and comparing quantitative variables, the arithmetic mean and their standard errors, the standard deviation and the Pearson correlation coefficient were calculated.

\section{RESULTS}

All of the patients with diabetes were in decompensated stage. The average level of glycosylated hemoglobin $(\mathrm{HbA} 1 \mathrm{c})$ was $8.3 \pm 0.3 \%$. Glucosuria was observed in 16 patients, ranged from 5 to $270 \mathrm{mmol} / \mathrm{l}$, on the average $114 \pm 46$ $\mathrm{mmol} / \mathrm{l}$. The following levels of GFR were observed in patients (Fig. 1). 28 patients had GFR in the range from 90 to $130 \mathrm{ml} \cdot \mathrm{min}^{-1} \cdot 1.73 \mathrm{~m}^{-2}$, in 17 patients GFR ranged from 89 to $60 \mathrm{ml} \cdot \mathrm{min}^{-1}$. $1.73 \mathrm{~m}^{-2}$, in 7 patients GFR was in the range of $60-45 \mathrm{ml} \cdot \mathrm{min}^{-1} \cdot 1.73 \mathrm{~m}^{-2}$, and in 1 patient the GFR was $42 \mathrm{ml} \cdot \mathrm{min}^{-1} \cdot 1.73 \mathrm{~m}^{-2}$.

Among 28 patients with GFR $90 \mathrm{ml} \cdot \mathrm{min}^{-1}$. $1.73 \mathrm{~m}^{-2}, 8$ patients had urinary syndrome. In $1 / 28$ patient, the urinary syndrome manifested as microalbuminuria and leukocyturia, 4/28 patients had isolated microalbuminuria from 0.03 to $0.1 \mathrm{~g} / \mathrm{L}$ and in $3 / 28$ patients had isolated leukocyturia from 8 to $100 \mathrm{wbc} / \mathrm{hpf}$. At the same 

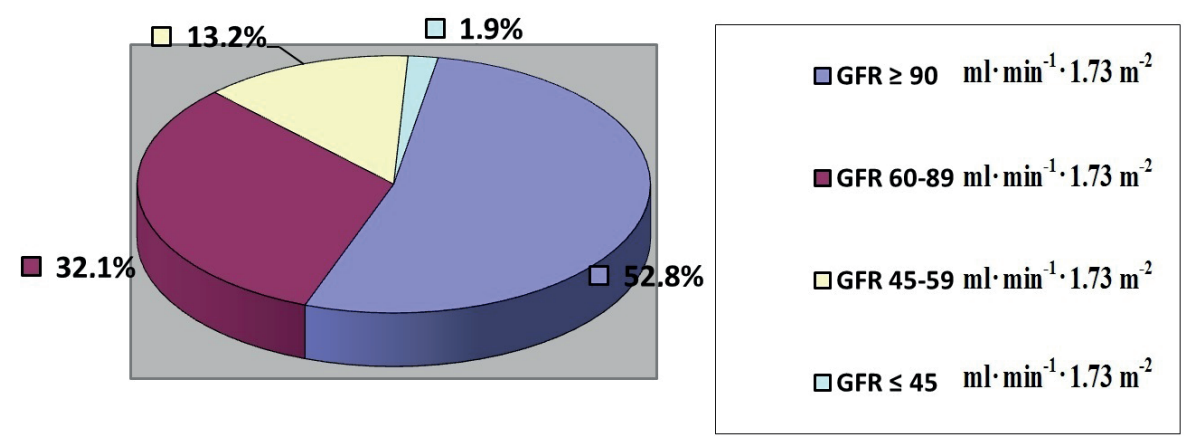

Fig. 1. GFR in patients with DM

time, $5 / 20$ patients, which urinary syndrome was not detected in, had renal changes observed by ultrasound investigation: dilated calyx to 20 $\mathrm{mm}$ was determined, and concrements up to 5 $\mathrm{mm}$ were detected. $15 / 28$ patients had no renal impairment (Fig. 2).

Among 17 patients with GFR $89-60 \mathrm{ml} \cdot \mathrm{min}^{-1}$. $1.73 \mathrm{~m}^{-2}, 4$ patients had urinary syndrome. In $1 / 17$ patient, the urinary syndrome manifested as microalbuminuria, microhematuria and leukocyturia, in 1/17 patient as microalbuminuria and leukocyturia. $3 / 17$ patients had isolated microalbuminuria $(0.02 \mathrm{~g} / 1)$ and $1 / 17$ patients had isolated leukocyturia (25-30 wbc/hpf). According to ultrasound investigation, in 3/17 patients renal tumors were diagnosed. 10/17 patients had no renal impairment.
Among 7 patients with GFR $59-45 \mathrm{ml} \cdot \mathrm{min}^{-1}$. $1.73 \mathrm{~m}^{-2}, 5$ patients had urinary syndrome. In $1 / 7$ patient, the urinary syndrome manifested as microalbuminuria, microhematuria and leukocyturia, in 1/7 patient as isolated leukocyturia. 2/7 patients had isolated microalbuminuria. In 1 patient besides leukocyturia, a high level of uric acid was detected. According to ultrasound investigation, $1 / 7$ patient had concrements of both kidneys up to $5 \mathrm{~mm}$ were found. $1 / 7$ patients had no renal impairment. There were no abnormalities from the kidneys in the patient with GFR $42 \mathrm{ml} \cdot \mathrm{min}^{-1} \cdot 1.73 \mathrm{~m}^{-2}$, the urinary syndrome was not diagnosed. The correlation between GFR and different indicators of urinary syndrome was not detected: microalbuminuria $(\mathrm{r}=-0.28)$, leukocyturia $(\mathrm{r}=-0.17)$, microhematuria $(\mathrm{r}=-0.31)$.

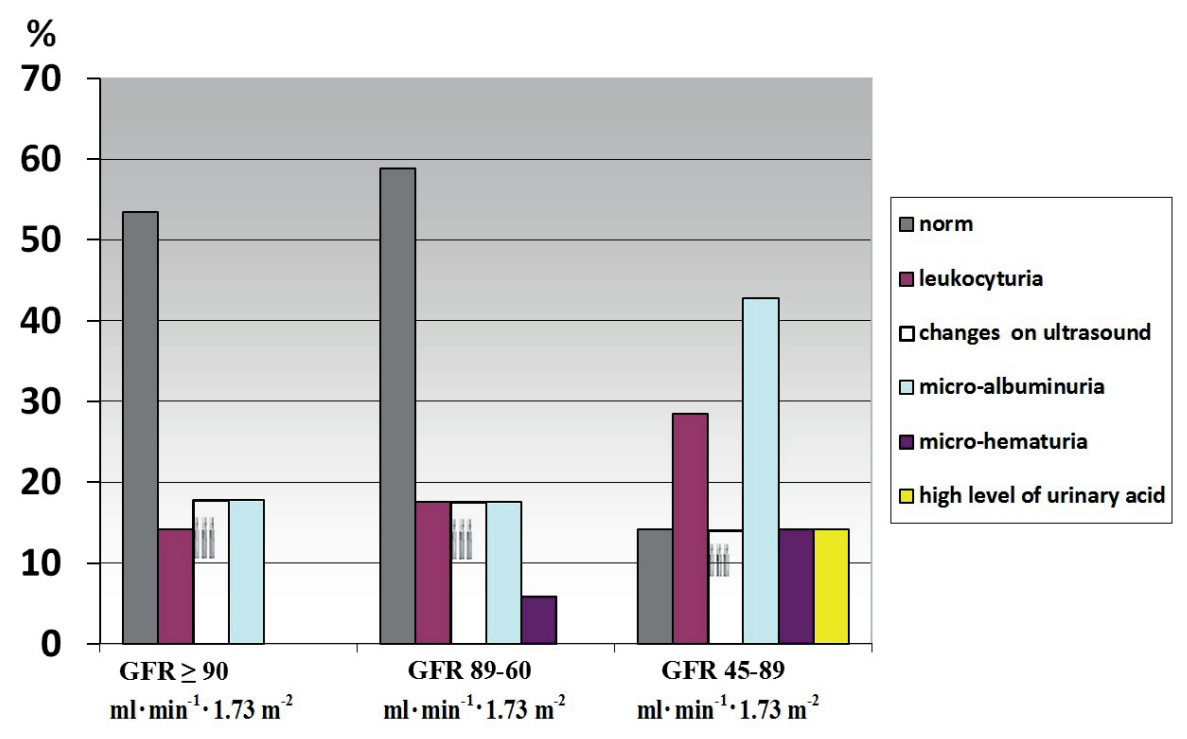

Fig. 2. Changes in urinary sediment and renal ultrasonography depending on GFR 
To estimate ED, depending on GFR, patients were divided into 2 groups. The first group consisted of 28 patients with GFR $\geq 90$ $\mathrm{ml} \cdot \mathrm{min}^{-1} \cdot 1.73 \mathrm{~m}^{-2}$, the second group consisted of patients with GFR ranging from 42 to 90 $\mathrm{ml} \cdot \mathrm{min}^{-1} \cdot 1.73 \mathrm{~m}^{-2}$ (Table). The following parameters were observed for groups of patients: the average age of patients was $50.3 \pm 5.7$ and 61.6 \pm 4.2 respectively. In patients of the first group, the duration of diabetes was $11.5 \pm 2.6$ years, in the second group it was $15.2 \pm 4.2$ years. The average level of $\mathrm{HbA} 1 \mathrm{c}$ in patients of both groups was the same and amounted to $8.3 \%$.

We have previously shown that in persons without endocrine and cardiovascular pathology, the level of CECs in blood plasma is $500 \pm$ 200 cells $/ \mathrm{ml}$ [18]. The concentration of CECs in blood plasma in patients with $G F R \geq 90$ $\mathrm{ml} \cdot \mathrm{min}^{-1} \cdot 1.73 \mathrm{~m}^{-2}$ was $3053 \pm 210.1$ cells $/ \mathrm{ml}$. The level of endotheliocythemia in patients with GFR from 42 to $88 \mathrm{ml} \cdot \mathrm{min}^{-1} \cdot 1.73 \mathrm{~m}^{-2}$ was higher by $22 \%$ and amounted to $3700 \pm 260.6$ cells $/ \mathrm{ml}$. At the same time, the level of $\mathrm{NO}_{2}{ }^{-}$at a norm of $0,05-4.2 \mu \mathrm{mol} / 1$, was $3 \pm 0.6 \mu \mathrm{mol} / 1$, and the concentration of $\mathrm{NO}_{3}{ }^{-}$, at a normal rate for humans $20-40 \mu \mathrm{mol} / 1$, was $31.5 \pm 7.2 \mu \mathrm{mol} / 1$. The concentration of $\mathrm{NO}_{2}{ }^{-}$and $\mathrm{NO}_{3}{ }^{-}$in patients of the second group was $3.4 \pm 0.7$ and $36.4 \pm$ $7.2 \mu \mathrm{mol} / 1$ respectively [19].

Among all the indicators listed in the table, the statistically significant difference was only in the CECs groups $(\mathrm{P}<0.05)$. Although the probability of ED increases with age due to the fact that age-related changes can summarize, the leading factor of ED is the damage of the vascular endothelium by hyperglycemia, which is manifested, in particular, by DN. Our early studies confirm the dependence of hyperglycemia on the amount of CECs [20].

\section{DISCUSSION}

In patients with diabetes, there was a significant increase in the level of CECs in blood plasma as the diabetic nephropathy progressed. With a decrease in the level of GFR, the concentration of CECs in the patients increased. In this regard, it can be assumed that hyperglycemia by glycosylation of proteins leads to damage of the vascular endothelium, including in the kidneys. Especially the capillary glomerulus suffers and, as a consequence, the glomerular filtration decreases. Thus, ED appears to be the main pathogenetic link of DN with an outcome in CKD due to a decrease in the number of functioning nephrons.

It should be noted that all other indicators of urinary syndrome do not correlate with the level of endotheliocythemia and the reduction of GFR, and, consequently, all other manifestations of the urinary syndrome are secondary to vascular damage in the kidneys. In this case, the primary change appears to be a change in the charge of the basal membrane of the glomeruli, which leads to an increase in the permeability for proteins followed by the appearance of microproteinuria. The further development of the pathological process in the glomeruli

Manifestations of ED in patients with diabetes depending on GFR

\begin{tabular}{|c|c|c|}
\hline INDICES & $\begin{array}{c}\mathrm{GFR} \geq 90 \mathrm{ml} \cdot \mathrm{min}^{-1} \cdot 1.73 \mathrm{~m}^{-2} \\
\mathrm{n}=29\end{array}$ & $\begin{array}{c}\text { GFR }<90 \mathrm{ml} \cdot \mathrm{min}^{-1} \cdot 1.73 \mathrm{~m}^{-2} \\
\mathrm{n}=24\end{array}$ \\
\hline AGE & $50.3 \pm 5.7$ & $61.6 \pm 4.2$ \\
\hline DURATION OF DM & $11.5 \pm 2.6$ & $15.2 \pm 4.8$ \\
\hline LEVEL OF HbA1c, \% & $8.3 \pm 0.5$ & $8.3 \pm 0.3$ \\
\hline CECs in $1 \mathrm{ml}$ & $3053.5 \pm 210.1 *$ & $3700 \pm 260.6^{*}$ \\
\hline $\mathrm{NO}_{2}^{-} \mu \mathrm{mol} / 1$ & $3 \pm 0.5$ & $3.4 \pm 0.6$ \\
\hline $\mathrm{NO}_{3}^{-} \mu \mathrm{mol} / 1$ & $31.5 \pm 7.2$ & $36.4 \pm 7.2$ \\
\hline
\end{tabular}

Note: * P-value between groups $<0.05$ 
leads ultimately to their sclerosis and death of nephrons and, consequently, to a decrease in GFR.

It is known that the dynamic process of the appearance and progression of ED involves several phases: compensatory activation of nitric oxide synthesis followed by the development of its exhaustion in combination with a low level of endothelium-dependent vasodilation. Based on this, it can be assumed that the normal mean concentration of $\mathrm{NO}_{2}{ }^{-}$and $\mathrm{NO}_{3}{ }^{-}$in these patients was a consequence of compensatory hyperactivation of the synthesis of nitric oxide. Therefore, at this period, compensation of the pathological process is still possible due to the intensification of nitric oxide synthesis and the correction of ED.

To assess the functional ability of the endothelium and the possible development of endothelial dysfunction, it is also necessary to determine other factors, which are synthesized by the endothelium, such as endothelin.

\section{CONCLUSION}

1. Diabetic nephropathy is manifested by a decrease in GFR, urinary syndrome.

2. The interconnection between indicators of the urinary syndrome and the degree of GFR reduction was not detected.

3. At the patients with DN, the number of circulating endothelial cells in blood plasma increases, indicating that vascular damage, including the kidney.

4. Endothelial dusfunction appears to be the main pathogenetic link of diabetic nephropathy

The authors of this study confirm that the research and publication of the results were not associated with any conflicts regarding commercial or financial relations, relations with organizations and/or individuals who may have been related to the study, and interrelations of coauthors of the article.
А.И. Гоженко, А.С. Кузнецова, Е.С. Кузнецова, Т.Н. Быць, Е.А. Гоженко, Н. А. Шевченко

ЦИРКУЛИРУЮЩИЕ В КРОВИ ДЕСКВАМИРОВАННЫЕ ЭНДОТЕЛИОЦИТЫ ПРИ ДИАБЕТИЧЕСКОЙ НЕФРОПАТИИ

Целью исследования было определить роль эндотелиальной дисфункции (ЭД) в патогенезе диабетической нефропатии у 53 пациентов с сахарным диабетом (СД) 1-го и 2-го типа с тяжелым течением в стадии декомпенсации. Диабетическая нефропатия проявлялась снижением скорости клубочковой фильтрации (СКФ) и мочевым синдромом. В зависимости от СКФ у пациентов с СД была произведена оценка ЭД по количеству циркулирующих дэсквамационных эндотелиальных клеток с одновременным определением метаболитов оксида азота $\mathrm{NO}_{2}^{-}$и $\mathrm{NO}_{3}^{-}$. Следует отметить, что показатели моченого синдрома не коррелируют со степенью снижения СКФ. Концентрация ЦЭК в плазме крови у пациентов со СКФ $\geq 90$ мл•мин $^{-1} \cdot 1,73 \mathrm{~m}^{-2}$ была $3053 \pm 210,1$ клеток/мл. Уровень эндотелиоцитемии у пациентов со СКФ от 42 до 88 мл•мин ${ }^{-1} \cdot 1,73$ м $^{-2}$ был выше на $22 \%$ и составил $3700 \pm 260,6$ клеток/мл. Таким образом, при диабетической нефропатии у больных СД в крови увеличивается количество циркулирующих эндотелиоцитов.

Ключевые слова: сахарный диабет; эндотелиальная дисфункция; диабетическая нефропатия; циркулирующие эндотелиальные клетки; скорость клубочковой фильтрации; сосудистый эндотелий; оксид азота.

\section{А.І. Гоженко, Г.С. Кузнецова, К.С. Кузнецова,} Т.М. Биць, О.А. Гоженко, Н.О.Шевченко

\section{ЦИРКУЛЮЮЧІ В КРОВІ ДЕСКВАМОВАНІ ЕНДОТЕЛІОЦИТИ ПРИ ДІАБЕТИЧНОЇ НЕФРОПАТІЇ}

Метою дослідження було визначити роль ендотеліальної дисфункції (ЕД) в патогенезі діабетичної нефропатії у пацієнтів 3 цукровим діабетом (ЦД) 1-го і 2-го типу 3 тяжким перебігом захворювання в стадії декомпенсації. Діабетична нефропатія проявлялась зниженням швидкості клубочкової фільтрації (ШКФ) та сечовим синдромом. Залежно від ШКФ у пацієнтів з ЦД була проведена оцінка ЕД за кількістю циркулюючих десквамаційних ендотеліальних клітин (ЦЕК) з одночасним визначенням вмісту метаболітів оксиду азоту $\mathrm{NO}_{2}{ }^{-}$i $\mathrm{NO}_{3}{ }^{-}$. Слід зазначити, що показники сечового синдрому не корелюють зі ступенем зниження ШКФ. У дослідженні показано, що концентрація циркулюючих десквамаційних ендотеліальних клітин в плазмі крові у пацієнтів з ШКФ $\geq$ 90 мл·хв ${ }^{-1} \cdot 1,73$ м $^{-2}$ була $3053 \pm 210,1$ клітин/мл. Рівень ендотеліоцитемії у пацієнтів з ШКФ від 42 до 88 мл· $\mathrm{XB}^{-1} \cdot 1.73 \mathrm{~m}^{-2}$ був вище на $22 \%$ і становив $3700 \pm 260,6$ клітин/мл. Таким чином, при діабетичній нефропатії у 
хворих на ЦД у крові збільшується кількість ЦЕК. Ключові слова: цукровий діабет; ендотеліальна дисфункція; діабетична нефропатія; циркулюючі ендотеліальні клітини; швидкість клубочкової фільтрації; судинний ендотелій; оксид азоту.

ДП «Украӥнський науково-дослідний інститут медицини mpaнсnорту, МОЗ України», Oдеса; e-mail: prof.gozhenko@gmail.com, hanna.serg.kuznetsova@gmail.com

\section{REFERENCES}

1. Tronko ND, Mankovsky BN. The state program "Diabetes mellitus". Treatment and diagnosis. 2009; 1: 58-9. [Russian].

2. Porush JM, Faubert PF. Hypertension, diabetes mellitus and nephropathy. London: Sience Preess. 2010; 9-12.

3. Kuznetsova ES, Kuznetsova AS, Shukhtin VV, Gozhenko AI. Particular qualities of the renal osmoregulatory function in patients with type 2 diabetes. Ukr J Nephrol Dialysis. 2015; 4(49): 21-6. [Russian].

4. Hill GS, Karoui KE, Karras A, Mandet C, Duong Van Huyen JP, Nochy D, Bruneval P. Focal segmental glomerulosclerosis plays a major role in the progression of IgA nephropathy. 2011 Mar; 79(6): 635-42. doi:10.1038/ ki.2010.466 PubMed PMID:21160460

5. El Karoui K, Hill GS, Karras A, Moulonguet L, Caudwell V, Loupy A, Bruneval P, Jacquot C, Nochy D. Focal segmental glomerulosclerosis plays a major role in the progression of IgA nephropathy. II. Light microscopic and clinical studies. Kidney Int. 2011 Mar; 79(6):643-54 doi: 10.1038/ki.2010.460.

6. Shamkhalova MS, Kurumova KO, Klefortova II, Sitkin II, Ilyin AV, Arbuzova MI, et al. Factors promoting development of renal tubulointerstitial lesions in patients with diabetes mellitus. Diabetes mellitus. 2010; 3: 13441. [Russian].

7. Editorial. Renal haemodynamics, vascular physiology, vascular pathology, experimental hypertension (W144W188). Nephrol Dial Transplant. 1Jun 2003; 18 Suppl 4: 593-607.

8. Fornoni A, Ijaz A, Tejada T, Lenz O. Role of inflammation in Diabetic Nephropathy. Curr Diab Rev. 2008; 4: 10-7. PubMed PMID: 18220690

9. Ferrera N. Vascular endothelial growth factor. Arterioscler Thromb Vasc Biol. 2009; 29: 789-91. DOI: 10.1210/ er.2003-0027.
10. Kizub IV, Klymenko KI, Soloviev AI. [Protein kinase C participation in mechanisms of vascular tone abnormality in diabetes mellitus. Part 2]. Pharmacol Drug Toxicol. 2014; 2 (38): 12-7. [Russian].

11. Kamp TJ, Hell JW. Regulation of Cardiac L-Type Calcium Channels by Protein Kinase A and Protein Kinase C. Circ Res, 2000. 87(12). 1095-102.

12. Gozhenko AI, Kuznetsova HS, Kuznetsova KS, Byts TN, Susla AB. Endothelial dysfunction in the pathogenesis of diabetes complications. The message I. Endothelial dysfunction: etiology, pathogenesis and diagnostic methods. Endocrinology. 2017; 22(2): 171-81. [Russian].

13. Martens CR, Edwards DG. Peripheral vascular dysfunction in chronic kidney disease. Card Res Pract. 2011; 2011: 257-67 http://dx.doi.org/10.4061/2011/267257.

14. Hladovec J, Prerovsky I, Stanek V, Fabian J. Circulating Endothelial Cells in Acute Myocardial Infarction and Angina Pectoris. Klin Wochenschr. 1978; 56(20): 1033-6.

15. Susla OB, Misula IR. inventors, State Higher Educational Institution Ternopil State Medical University named after I. Ya. Gorbachevsky, assignee. Method for determining the content of circulating endothelial cells in the blood plasma. Ukraine Patent 57841, MPK A61V10/00. 2010 Sep 20. [Ukranian].

16. Gao Y, Liu C, Zhang X, Gao J, Yang C. Circulating Endothelial Cells as Potential Markers of Atherosclerosis. 2008 Nov; 35(5): 638-642 https://doi.org/10.1017/ S0317167100009446.

17. Stevens LA, Claybon MA, Schmid CH, Chen J, Horio M, Imai E, et al. Evaluation of the Chronic Kidney Disease : Epidemiology Collaboration equation for estimating the glomerular filtration rate in multiple ethnicities. Kidney Int. 2011 Mar; 79(5): 555-62. doi:10.1038/ki.2010.462

18. Gozhenko AI, Kuznetsova HS, Kuznetsova KS, Kuznetsova OM, Byts TM, Zukow W. Morpho-functional basis of endothelial dysfunction in diabetes mellitus. Journal of Education, Health and Sport. 2017; 7(6):516-24. eISSN 2391-8306. doi http://dx.doi.org/10.5281/zenodo.822050. [Russian].

19. Kobylyanskiy AG, Kuznetsova TV, Soboleva GN. Determination of nitric oxide in the serum and plasma of the human blood. Method of high-efficient liquid chromatography. Biomed Chem. 2003; 49(6): 597-603. [Russian].

20. Gozhenko AI, Kuznetsova HS, Olenovych OA, Kuznetsov SH, Kuznetsova KS, Byts TM. The number of circulating endotheliocytes in the blood plasma of the patients with diabetes mellitus increases.. Pharmacologyonline. 2017.3, 23-6. 